JEL: D24, G32, Q14

Olena Lemishko

\author{
National University of Life and Environmental Sciences of Ukraine
}

Ukraine

\title{
FORMATION OF ANALYTICAL TOOLS OF CAPITAL REPRODUCTION IN THE AGRICULTURAL SECTOR OF UKRAINE
}

Purpose. The purpose of the article is to form analytical tools for the capital reproduction in the agricultural sector of Ukraine's economy for substantiation of management decisions to ensure its continuous recovery, progressive growth of its value on the basis of positive qualitative changes in capital at its optimal structural proportions.

Methodology / approach. Such scientific methods were used in the article to achieve the purpose of the research: structural and logical analysis - to form a holistic conceptual approach to research; comparison - to substantiate the peculiarities of the reproduction of capital at the macro level and in the agricultural sector of the economy; statistical method-for processing information that characterizes the value and structural proportions of capital of economic entities in the agricultural sector of the economy.

Results. Elaboration of analytical indicators of the passive part of the balance of economic entities of agriculture, forestry, fisheries of Ukraine revealed that there is an increase of equity capital relative to its cost value, but a decrease in its share in the total capital structure, namely a decrease of cost estimate of equity capital relative to borrowed capital occurs 3.5 times more intensely; during 2010-2018, total capital, equity capital and gross value added of enterprises of the national economy of Ukraine, as well as the agricultural sector of the economy showed sustainable growth, but in the agricultural sector of the economy there was a decrease in the share of gross value added in total capital of enterprises that proved the tendency of potential narrowing the sources of ensuring the reproduction of capital; during the study period, the level of real capitalization in the agricultural sector of Ukraine's economy decreased significantly; dynamic changes in indicators of financial stability of agricultural enterprises confirmed that in 2018 agricultural enterprises were able to finance their assets at the expense of equity by only $49 \%$ (in $2001-66 \%$ ), financial stability of agricultural enterprises in 2018 lagged behind the optimal allowable value by 12 percentage points, in contrast to 2001 (exceeding the optimal allowable value by 3 percentage points), which encouraged an increase of financial risks in agriculture.

Originality / scientific novelty. Financial diagnostics of cost and structural characteristics of capital of economic entities in the agricultural sector of Ukraine's economy revealed that in the agricultural sector there is a paradoxical situation: the dynamics of retained earnings growth in the structure of equity capital, accompanied by declining dynamics of equity in the total amount of total capital and narrowing of cost estimates of equity in relation to GDP. It is proved that the formation of optimal proportions of capital is one of the factors ensuring expanded reproduction of capital, therefore, the mechanism of implementation of financial policy of capital reproduction should be aimed at increasing internal sources of capital formation and optimizing the structure of total capital. Given that the agricultural sector of Ukraine with its basic component, farming, is a system-forming component in the national economy and forms the basis for preserving the sovereignty of the state (food, economic, environmental and energy security within certain limits), we assume that further accumulation of negative trends from the perspective of values and structural proportions of capital in the agricultural sector of Ukraine's economy may be the basis 
for the acquisition of a state of financial fragility in the economic system as a whole.

Practical value / implications. To harmonize certain norms of capital formation of Ukrainian enterprises, it is proposed to take into account the "fixed capital system», enshrined in the second EU Directive and to establish at the legislative level the procedure for capital formation for limited liability companies (LLCS): guaranteed real contribution of authorized capital should be at the level of the cost values of net assets of the company; to consider such level as the minimum admissible.

Key words: capital reproduction, agricultural sector, formation of analytical tools, structural proportions, financial policy.

Introduction and review of literature. The agricultural sector of the economy determines the possibility of the existence of the state, as it is the basis of the full cycle of reproduction of ecological balance, social welfare, material goods, and capital. The disadvantages of modern state agricultural policy in Ukraine are: imbalance and lack of consistency and complexity; frequent change of tactics and strategy; lack of preconditions for creating favorable, equal conditions for successful development of all participants of the agricultural market; unsatisfactory regulation of the agricultural market to establish free competition; lack of coherence of purposeful incentives, restrictions and prohibitions in the formation of the agrarian system and system-forming model of interconnected development of the agricultural sector of the economy and rural areas, etc. [1, p. 6]. The inconsistency and instability of the institutional components of agricultural policy did not contribute, among other things, to an increase in the amount of own funds of economic entities in the agricultural sector of the economy, increase value added and real sources of capitalization of the economy. As a special area of capital formation, the agricultural sector forms the financial resources of the state, directly affects the growth of economic efficiency, which is reflected in the level of national income. The reproduction of capital in the agricultural sector of the economy is associated with its organic structure, and is subject to the reproduction of the entire system of socio-economic relations. Activation of the role of capital in the process of social production requires analytical research and diagnosis of the formation of cost values and structural proportions of capital. The formation of analytical tools for capital reproduction is subject to the study of capital structure, determining the share of debt instruments in financing economic activities, development of indicators of financial stability and financial stability, as well as substantiation of financial independence of capitalized sources and their impact on reproduction processes.

The issue of improving the methods of diagnostics of the financial and economic mechanism of regulation of capital formation processes is paid attention in the works of the following scientists: V. Heiets [2], A. Danylenko [3], A. Turylo [4]. Practical aspects of capital reproduction and investment support of the agricultural sector of the economy have been studied by such scientists as A. Balitska [5], N. Davydenko [6], L. Kostyrko [7] and others. Indicators of macroeconomic proportions and promising sources of funding are defined in the works of A. Sholoiko [8]. Theoretical and methodical bases of providing sustainable development are defined by A. Kasych 
[9]. Modeling of sources of financing the capital of agricultural enterprises in the Czech Republic and Ukraine is highlighted in the study of O. Oliynyk-Dann and P. Zufan [10]; diagnosis of key indicators of fiscal policy in the agricultural sector of Poland is conducted by M. Solovida and J. Pavlovska-Tyshko [11]. Market priorities of agricultural production are studied in the works of O. Labenko [12] and S. Kvashi [13]; sources of capital attraction, as a necessary condition for the formation of an effective investment mechanism in the agricultural sector are developed by I. Novak, Y. Novak and N. Vernyuk [14]. A study of the methodology for assessing the investment attractiveness of agrarian business is conducted by N. Levchenko and V. Okhlikh [15]; Z. Zadorozhny and V. Yasyshena [16] identified the main areas of intangible asset management. Despite the constant interest of economists in solving the complex and multifaceted problem of the functioning of capital at the macro and micro levels, an objective assessment of the determining parameters of capital reproduction remains relevant. The need for a detailed study of the factors influencing the formation of reproductive proportions of capital in the agricultural sector of the economy, the dynamics of their change have determined the relevance and practical significance of the study.

The purpose of the article is to form analytical tools for the reproduction of capital in the agricultural sector of Ukraine's economy for substantiation of management decisions on ensuring its continuous recovery, progressive growth of its value on the basis of positive qualitative changes in capital at its optimal structural proportions.

Results and discussion. According to economic laws, real GDP growth must occur, including through the growth of labor and capital (i.e., through the growth of basic factors of production). In our opinion, the most important generator of state GDP growth in the formation of certain competitive areas of the economy is capital. Reproduction of the capital of the economic system is possible on the basis of achieving optimal parameters of volume and structure and its effective placement [5, p. 101], as well as the optimization of primary incomes generated by participants in production and distributed among them (value added). Therefore, it is advisable to diagnose the trend of formation of total capital, equity and value added at the macro level. During 2010-2018, total capital, equity and gross value added of enterprises of the national economy of Ukraine, as well as the agricultural sector of the economy showed a stable growth, as evidenced by the description of their dynamics by a parabola with a multiple coefficient of determination close to 1 (Fig. 1, 2).

For the period 2012-2018, the rate of increase in value added (total number of enterprises of the national economy) was 2.77 and exceeded the rate of increase in equity (1.42). The opposite trend is in the agricultural sector of Ukraine's economy (2010-2018): the growth rate of equity (5.34) is almost twice as high as the growth of value added (2.71). During 2010-2018, the share of gross value added in the total capital of agricultural enterprises (agriculture, forestry, fisheries) decreased from $33.2 \%$ to $20.5 \%$. 


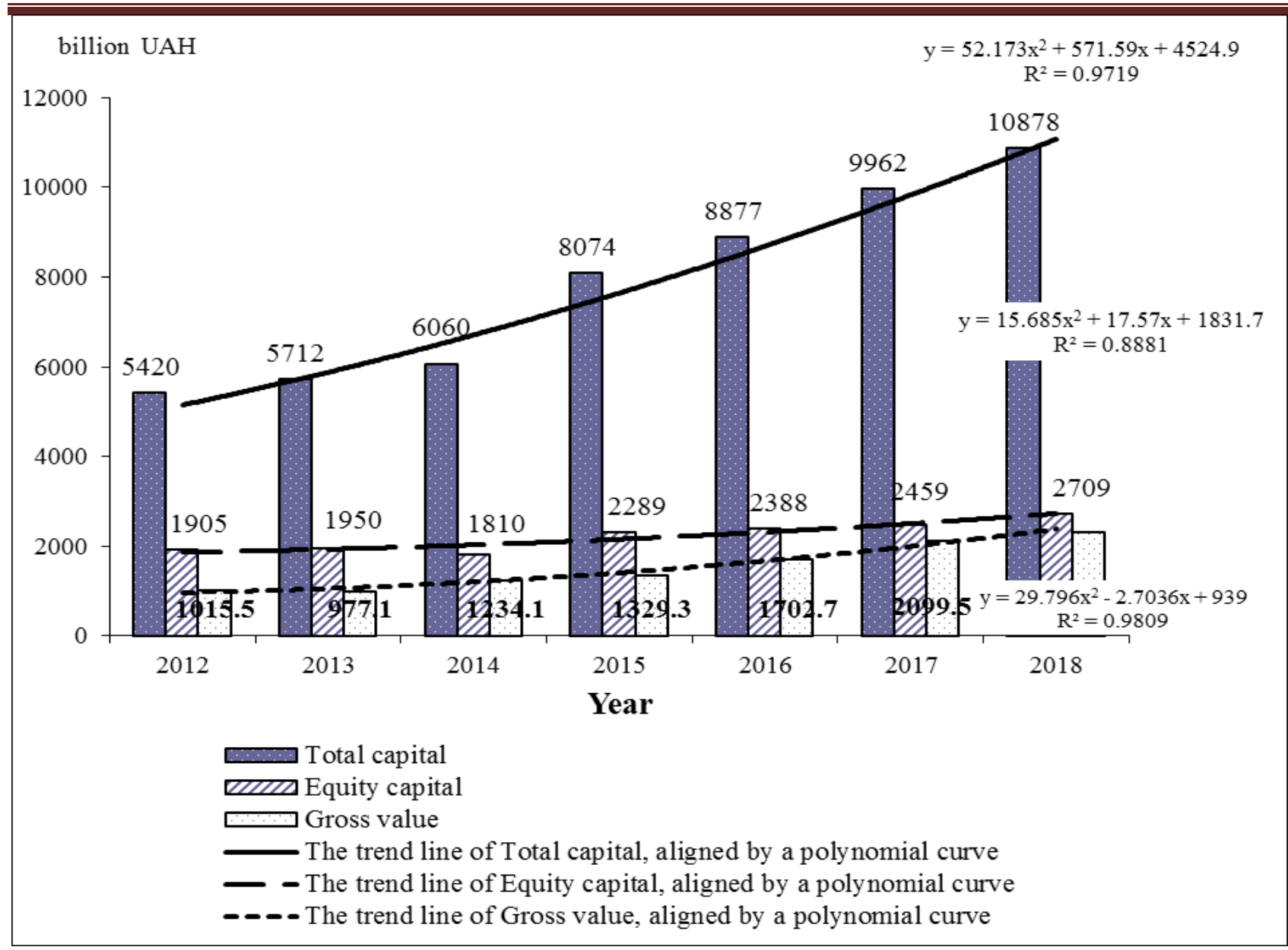

Fig. 1. Dynamics of total capital, equity, gross value added in the enterprises of the national economy of Ukraine

Source: built by the author based on data [17].

It is the value added that will be determined by the value of the reproduced capital. The decrease in the share of gross value added in total capital proves the tendency of potential narrowing of sources of capital reproduction in the agricultural sector of the economy. The increase in gross value added is a prerequisite for expanded reproduction of capital as a process of continuous recovery on the basis of progressive growth of cost values, due to positive qualitative changes in capital at its optimal structural proportions.

We note that the results of the analysis of the process of capital reproduction at individual enterprises are limited and therefore do not determine and do not prove the general trends of capital reproduction at the state and industry levels, in particular. At the same time, the study of sources of capital formation, its movement and reproduction in relation to the whole set of enterprises, determines the level of capitalization of the economy, and business entities are the main participants in the sphere of production and consumption. Features of decision-making on the structure of sources of capital formation are one of the most pressing problems of modern financial theory, the practical significance of which is confirmed by negative trends identified at the macro and micro levels, namely: deteriorating capital structure, reducing the financial stability of enterprises, narrowing the base for accumulation of 
capital and deepening of contradictions between the current levers of influence of institutional-legal and financial-economic mechanisms of regulation of capital formation processes in Ukraine $[2-5 ; 18 ; 19]$.

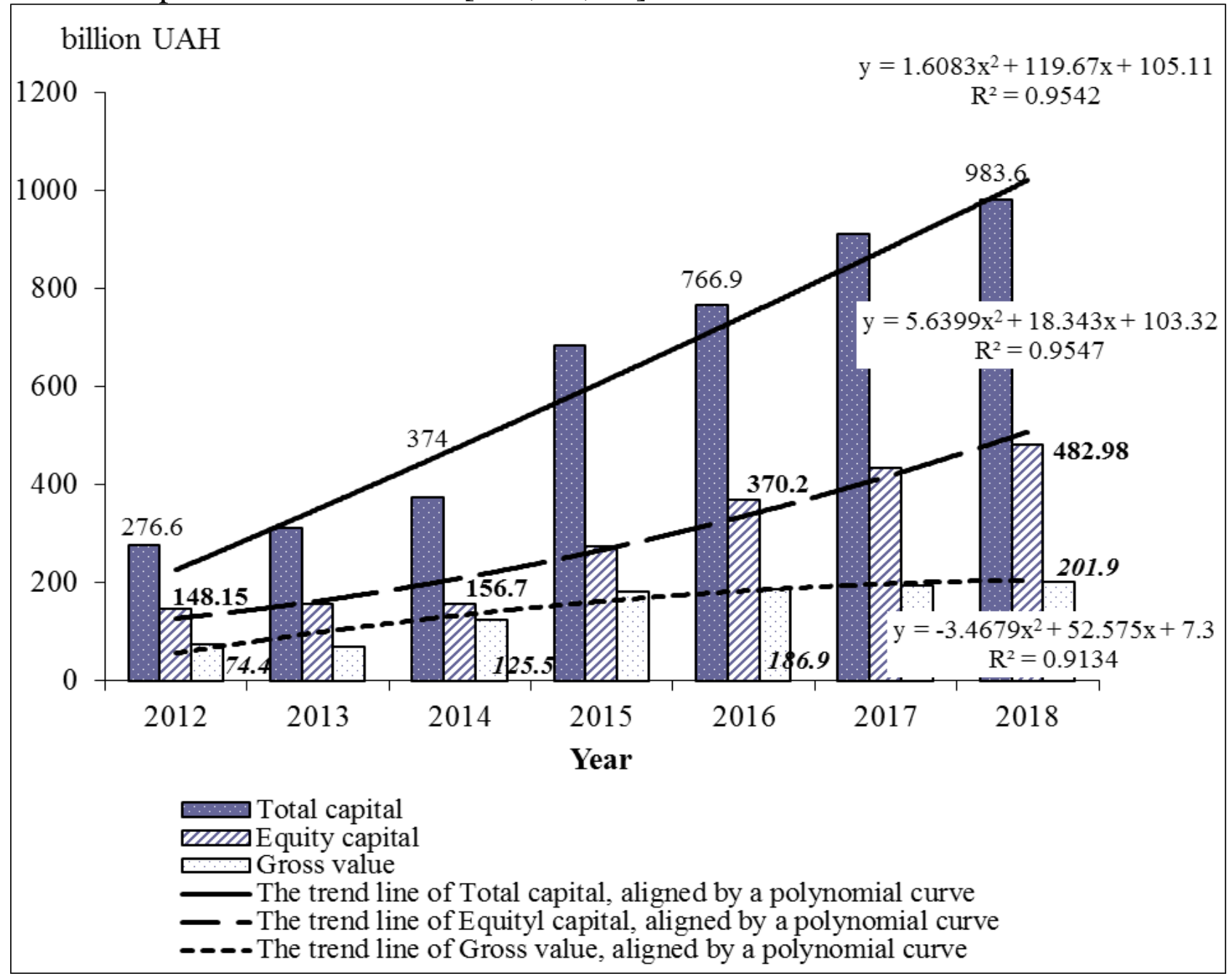

Fig. 2. Dynamics of total capital, equity, gross value added in agriculture, forestry, fisheries of Ukraine

Source: built by the author based on data [17].

The condition for the effective functioning of reproduction processes is a balance of own and borrowed sources of financing. Given that the capital structure plays a crucial role in the reproduction process, we consider it potentially productive to diagnose the cost values and structural proportions of capital in the agricultural sector of Ukraine for the holistic vision of the features of capital formation trends in the agricultural sector of the economy. The dynamics of sources of capital formation of economic entities for the period 2001-2018 had a negative trend of structural deformation due to a decrease in the share of own sources of capital formation (Table 1). The study of analytical indicators of the passive part of the balance sheet (Table 1) showed that there is an increase in equity relative to its value, but a decrease in its share in the structure of total capital. For the period 2001-2018 the valuation of equity of economic entities in agriculture, forestry and fisheries of Ukraine increased 11.64 times (from 41.51 billion UAH in 2001 to 482.98 billion 
UAH in 2018), and its share decreased by 17 percentage points in the structure of total capital (from $66 \%$ to $49.1 \%$ ). At the same time, the cost of borrowed capital for the same period increased 23.14 times (from 21.63 billion UAH in 2001 to 500.61 billion UAH in 2018). Thus, the decrease in the value of equity relative to borrowed capital in the agricultural sector of Ukraine's economy is 3.5 times more intense.

Table 1

Dynamics and capital structure (liabilities) of economic entities agriculture, forestry, fisheries of Ukraine, 2001-2018, billion UAH

\begin{tabular}{|l|c|c|c|c|c|c|c|c|}
\hline $\begin{array}{c}\text { Balance sheet items } \\
\text { (liability) }\end{array}$ & 2001 & 2003 & 2007 & 2013 & 2016 & 2017 & 2018 & $\begin{array}{c}2018 / \\
2001, \\
+,-\end{array}$ \\
\hline Equity & 41.51 & 34.40 & 49.87 & 156.82 & 369.37 & 436.34 & 482.98 & 441.47 \\
\hline$\%$ & 65.7 & 58.1 & 55.5 & 50.1 & 24.0 & 47.9 & 49.1 & -16.6 \\
\hline $\begin{array}{l}\text { Ensuring subsequent } \\
\text { costs and payments }\end{array}$ & 0.72 & 0.64 & 0.74 & - & - & - & - & - \\
\hline$\%$ & 1.1 & 1.1 & 0.8 & - & - & - & - & - \\
\hline Long-term liabilities & 3.76 & 5.01 & 12.05 & 43.03 & 61.89 & 59.08 & 82.25 & 78.49 \\
\hline$\%$ & 6.0 & 8.5 & 13.4 & 13.7 & 4.0 & 6.5 & 8.4 & 2.4 \\
\hline Current liabilities & 17.05 & 18.98 & 26.79 & 113.18 & 1105.99 & 416.15 & 418.28 & 401.23 \\
\hline$\%$ & 27.0 & 32.0 & 29.7 & 36.2 & 71.9 & 45.6 & 42.2 & 15.2 \\
\hline Deferred income & 0.10 & 0.20 & 0.64 & - & - & - & - & - \\
\hline$\%$ & 0.2 & 0.3 & 0.7 & - & - & - & - & - \\
\hline $\begin{array}{l}\text { Liabilities related to } \\
\text { non-current assets and } \\
\text { disposal groups }\end{array}$ & - & - & - & 0.065 & 0.058 & 0.050 & 0.08 & - \\
\hline$\%$ & - & - & - & 0.02 & 0.004 & 0.005 & 0.0001 & - \\
\hline Balance & 63.14 & 59.23 & 90.09 & 313.10 & 1537.30 & 911.61 & 983.59 & 920.45 \\
\hline$\%$ & 100.0 & 100.0 & 100.0 & 100.0 & 100.0 & 100.0 & 100.0 & - \\
\hline
\end{tabular}

Source: built by the author based on data [17].

Given the identified negative trends in capital formation, we conclude that during the study period, the level of real capitalization in the agricultural sector of Ukraine's economy has decreased significantly. The process of formation of cost and structural proportions of total capital directly affects the process of its accumulation, i.e. the process of expanded reproduction of capital. In the sense of ensuring sustainable economic development and capital accumulation, which should be considered as a process of increasing all elements of capital and the formation of economic conditions of its existence, performs the following main functions: meeting the needs of expanded reproduction and increasing the welfare $[20 ; 21]$. The formation of the optimal proportions of capital and the optimization of its structure, is one of the factors ensuring the expanded reproduction of capital. The mechanism of implementation of the financial policy of capital reproduction should be aimed at increasing the internal sources of capital formation and optimizing the structure of total capital. To guarantee national economic security, consolidate the role of the state as one of the leading European countries, meet the socio-economic needs of 


\section{Agricultural and Resource Economics: International Scientific E-Journal http://are-journal.com}

society, the financial policy implemented by the state should be able to promote such economic relations between the subjects of the reproduction process, which will ensure the development of the economy and its individual industries [22, p. 119; 23].

The amount of equity is considered one of the most important indicators used in assessing the financial condition of enterprises, and the book value of equity capital is the main indicator of financing economic activity, as it is available to enterprises constantly [5, p. 105]. The primary financial source of economic activity, which is expressed in a certain value of the property, and is the contribution of the owners (participants) to the capital of the enterprise, is the authorized capital. The amount of authorized capital may not be less than the amount established by law and depends on the choice of one or another organizational and legal form of management. The exception is farms. It should be noted that according to the Law of Ukraine «On farming» [24], the property of a farm (composed capital) may include: buildings, structures, arrangements, material values, securities, products, etc.; the amount of the capital of the farm is not regulated by law.

Endogenous sources of equity formation are retained earnings and reserve capital, which by their nature are accumulated capital in the course of the entity's operation. The company, as a rule, aims to obtain a positive dynamic of profitability and consolidate it in the long run. The process of profit distribution reveals its impact on the reproduction of capital and current consumption. In the context of financial support for enterprise development, such a process includes the distribution of total profits, the participants of which are the state and the enterprise and the distribution of net profit (remaining at the disposal of enterprises after payments to the budget) $[7 ; 25$, p. 182]. Filling the equity of economic entities in the agricultural sector by $76.4 \%$ in 2018 was due to retained earnings and reserve capital (Fig. 3). Given that retained earnings are an endogenous source of reproduction of equity of enterprises, the growth of retained earnings in equity is one of the factors strengthening financial stability and increasing market value of the enterprise. Financial diagnostics of cost and structural characteristics of capital of economic entities of the agricultural sector of the economy, as well as analytical studies of macroeconomic indicators, found that in the agricultural sector of the economy there is a paradoxical situation: the dynamics of retained earnings in the structure of equity is accompanied by declining dynamics in the share of the total capital and the narrowing of the cost value of equity in relation to GDP. Analyzing the qualitative content of equity (sources of its formation) (Fig. 3), we draw the following conclusions: the share of authorized capital in the total amount of equity of economic entities in agriculture of Ukraine since 2007 until 2018 decreased by 19.0 percentage points. This significant decline is explained by the fact that the amount of authorized capital was consistently changed (decreased) on a legislative basis over a long (1991-2018) period of time. The amendments introduced by the Law of Ukraine № 3263-VI of April 21, 2011 completely excluded the requirements for the minimum size of the authorized capital of limited liability companies (LLCs), additional liability companies and limited partnerships from the legislation (in particular from Article 52 of the Law of Ukraine) [26]. 


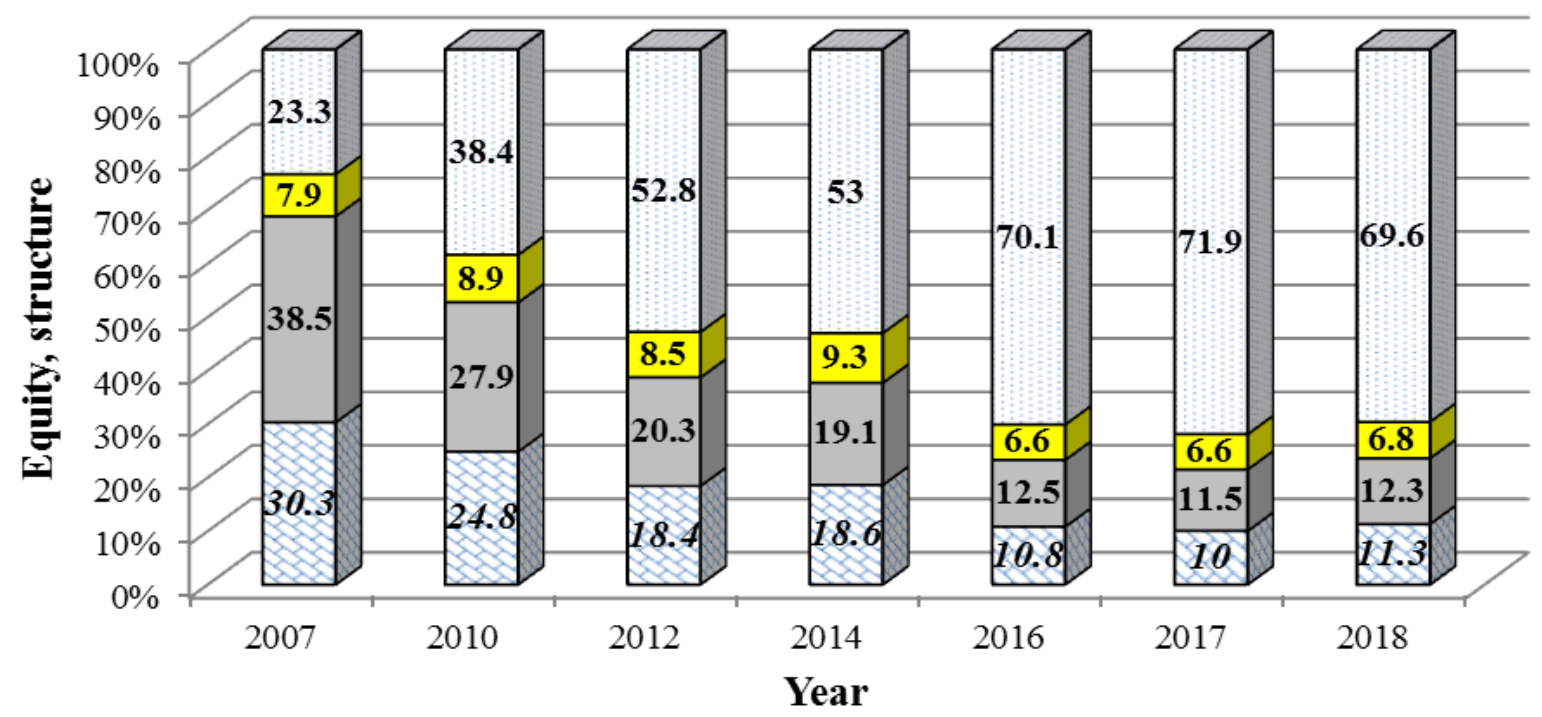

$\square$ Authorized capital (registered) $\square$ Additional capital $\square$ Reserve capital $\square$ Undivided profit

\section{Fig. 3. The structure of equity of economic entities in agriculture, forestry and fisheries of Ukraine, 2007-2018, \%}

Source: built by the author based on data [17].

For private enterprises, the size of the authorized capital is not set [27]. The minimum size of the authorized capital of the Joint-Stock Company is 1250 minimum wages (from 01.01.2018 to 31.12.2018, this amount is 4653750 hryvnias): the requirements for the authorized capital of companies are defined by the relevant legislation in Art. 52 and Art. 65 of the Law of Ukraine "On business associations» of 19.02.91 № 1576-XII, as well as in Art. 14 of the Law of Ukraine «On joint-stock companies» dated 17.09.2008 № 514-VI for JSCs established on 30.04.2009, and JSCs, the internal provisions of which are brought in line with the provisions of this Law [28; 29].

Important in the formation of the authorized capital is the legislative consolidation of the possibility of increasing it by making additional contributions and without additional contributions at the expense of the company's profit, which was not distributed [30]. In fact, the authorized capital remains a financial indicator that characterizes the initial source of equity formation and outlines the scope of corporate rights of its participants. However, the value of the authorized capital of companies is reduced to the minimum possible divisible amount: «from one kopeck if there is only one participant in the company, and up to one hundred kopecks (one hryvnia) - if the number of participants in a limited liability company reaches one hundred people as the maximum possible value allowed by law» [31, p. 219-220]. This situation prompted entrepreneurs to minimize their own investments in the authorized capital of the enterprise. The source of increase in authorized capital may be additional capital. Regarding our study, the following aspect is important: the composition of additional capital, in accordance with paragraph 19 Regulation 
(standart) of Accounting Exchange 7 «Fixed assets», includes the amount of revaluation of the residual value of fixed assets. Unfair assessment of the value (property) of enterprises, especially in terms of fixed assets, is one of the reasons for underestimation of the value of the authorized capital and, in particular, equity [5, p. 108-109; 168], which, in turn, negatively affects the process of capital formation. At the same time, the actually underestimated value of fixed capital narrows the possibilities of the reproduction process. Given that additional capital can be used as a source to cover balance sheet losses (provided that all other sources are used) and to cover the difference between the actual cost of withdrawn capital, which is canceled, and its face value, the tendency to reduce the share of additional capital in total equity capital from $38.5 \%$ (in 2007) to $12.3 \%$ (in 2018), negatively affects the process of capital increase in the process of economic and financial activities of economic entities in agriculture, forestry and fisheries of Ukraine.

Regarding the legal basis for the formation of equity, it is necessary to note the following. Ukraine's integration into the European Union is subject to the adaptation of our country's legislation to EU legislation. The European model of functioning of the agricultural sector of the economy proved to be productive both economically and socially [6]. In this aspect, the EU corporate law directives are important, which regulate the formation of different types of companies and harmonize certain capital formation norms. We propose to pay special attention to the «fixed capital system» enshrined in the Second EU Directive.

This system is one of preliminary control to ensure the interests of shareholders and creditors at the stage of establishment of the company [32] and guarantees the actual contribution of authorized capital, in the amount determined by law, by establishing a company. Given that European integration has been chosen as a priority for Ukraine's development, we consider it appropriate to amend the legal documents on guaranteed real contribution of authorized capital at the value of the company's net assets and consider this level the minimum allowable. Methodologically, this does not contradict the essence of the concept of «capital», its inherently dual nature. It should be noted that the study of a set of problems of international integration as a methodological basis involves a systematic study of the comparison of profiles of managers of countries entering the integration. Such studies on the example of developing prospects for Polish-Ukrainian integration cooperation were initiated by B. Glinkowska and V. Chebotariov [33; 34]. A necessary logical continuation of such an analysis is to clarify the features of commonality and differences of national business cultures of the European Community, which will be useful for both social and economic development of Ukraine. Theoretical and methodological aspects of sustainable growth of companies and the mechanism of optimization of this process, which is based on, inter alia, the diagnosis of indicators of capital formation were developed by A. Kasych and M. Vochozka [9]. The ratio of equity and total capital characterizes the indicator of financial autonomy - one of the most important indicators of financial stability. Analytical data (Fig. 4) showed that in $201849.0 \%$ of agricultural enterprises were able to finance their assets at the 
Agricultural and Resource Economics: International Scientific E-Journal http://are-journal.com

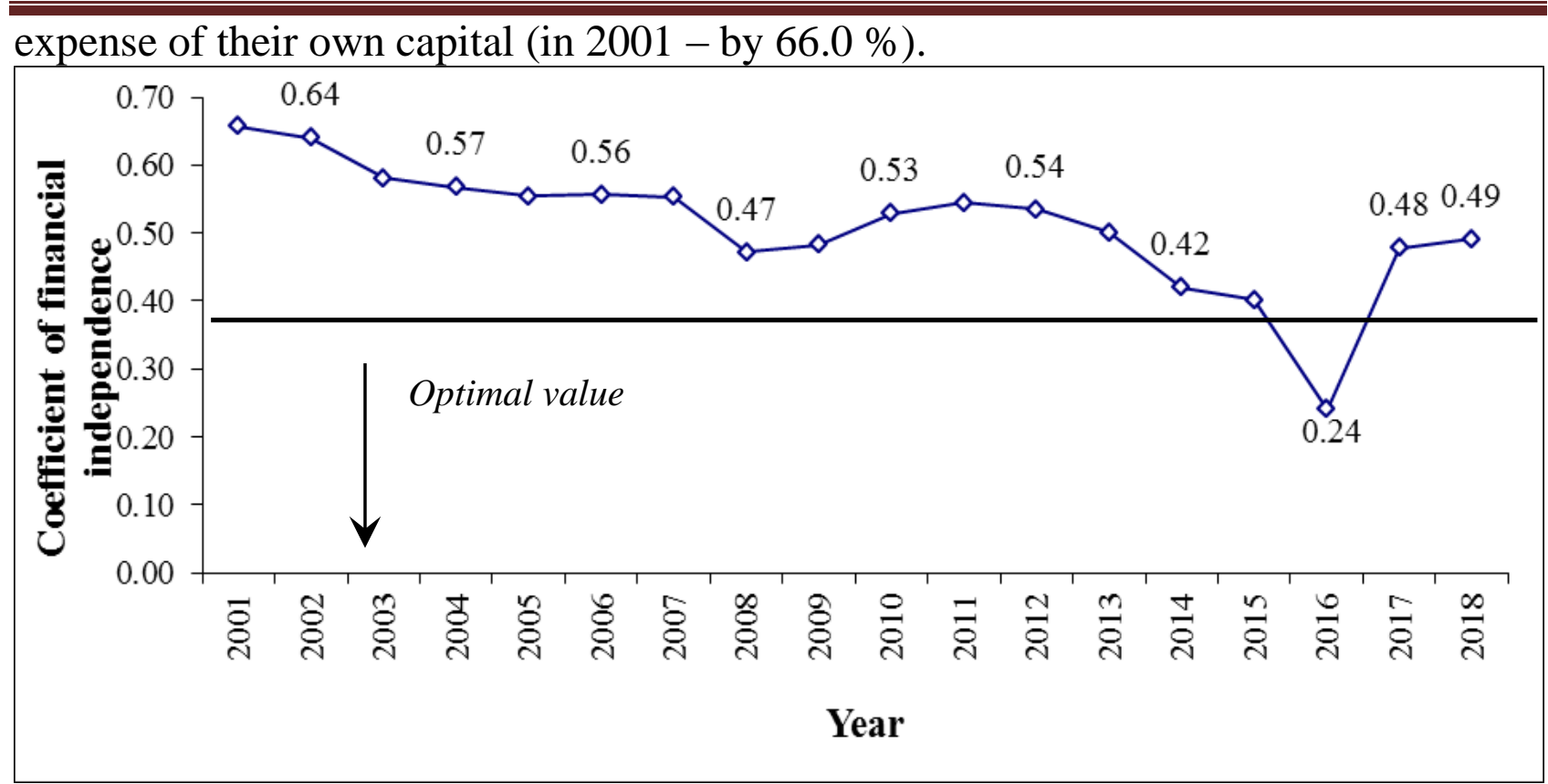

Fig. 4. Coefficient of financial independence (autonomy) of economic entities in agriculture, forestry and fisheries of Ukraine

Source: built by the author based on data [17].

The size of borrowed capital also has a significant impact on financial stability. Methods for assessing financial stability at the micro level were developed in the scientific work of I. Boyarko, O. Lyuta and N. Pigul [35]. The ratio of equity to borrowed capital is characterized by the coefficient of financial stability. Stability in the long run is especially important when the market situation is changed. In 2018 this indicator lagged behind the optimal allowable value by 12 percentage points, in contrast to 2001 (exceeding the optimum allowable value by 3 pp) (Fig. 5).

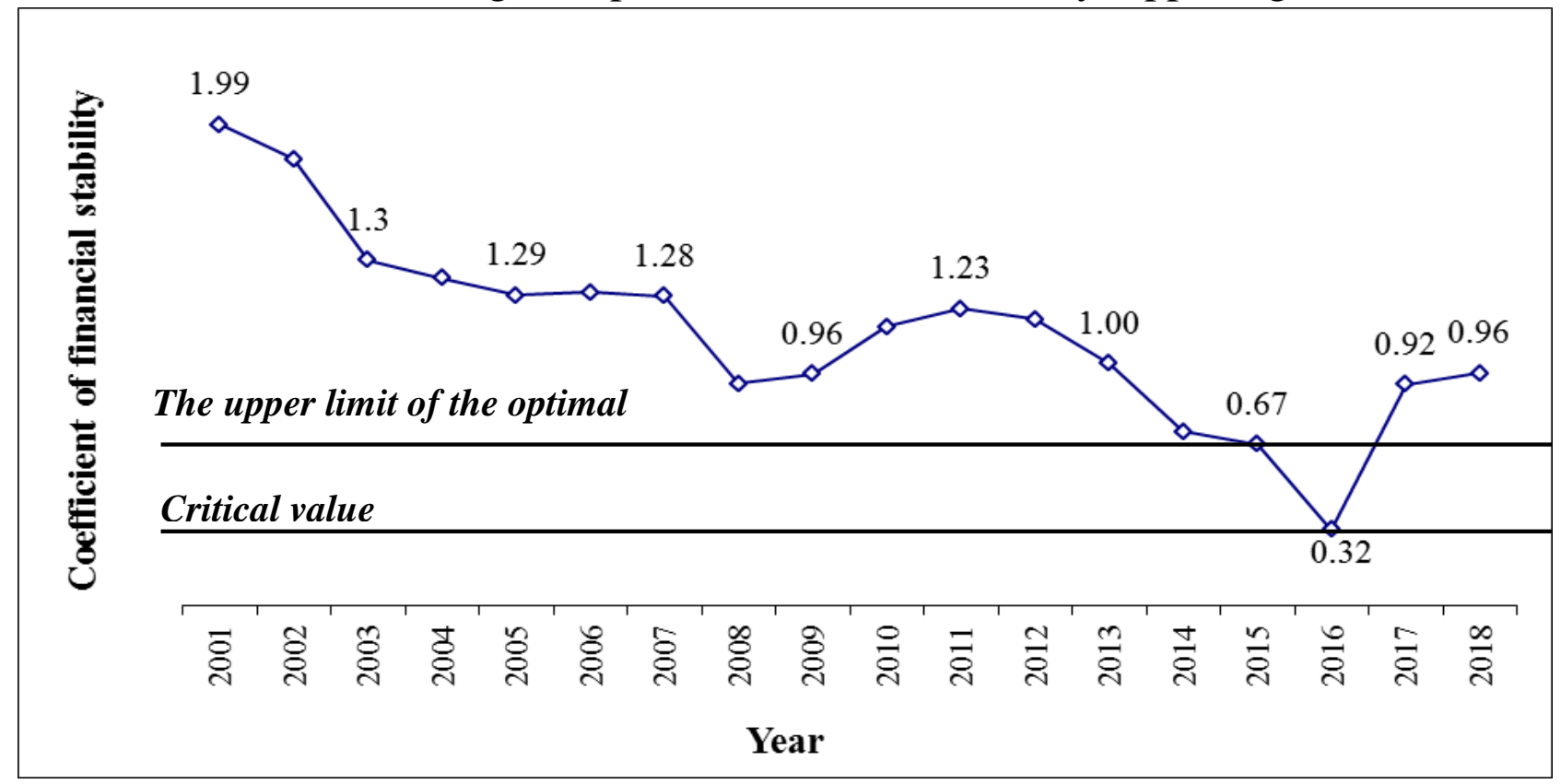

Fig. 5. Coefficient of financial stability of economic entities in agriculture, forestry and fisheries of Ukraine

Source: calculated and built by the author based on data [17]. 
The value of the indicator defines that in 20180.92 UAH per one UAH of the entity's liabilities in agriculture of Ukraine. In 2001 each hryvnia of liabilities was covered by $1.1 \mathrm{UAH}$ of equity. This negative trend generates an increase in financial risks in agriculture. A number of authors express an opinion on the possibility of stable operation of the enterprise in conditions of high financial dependence on borrowed capital [36-38].

However, we believe that such a conclusion is not appropriate, as an unpredictable change in the market situation may lead to the fact that the company, in conditions of high financial dependence on borrowed capital, will not be able to meet interest and return obligations to the credit; the operation of the enterprise will be threatened. The share of own and long-term borrowed funds in the structure of total capital is characterized by the coefficient of financial stability (Fig. 6). The financial stability of agricultural enterprises during the study period was decreased significantly - from 0.72 (2001) to 0.57 (2018).

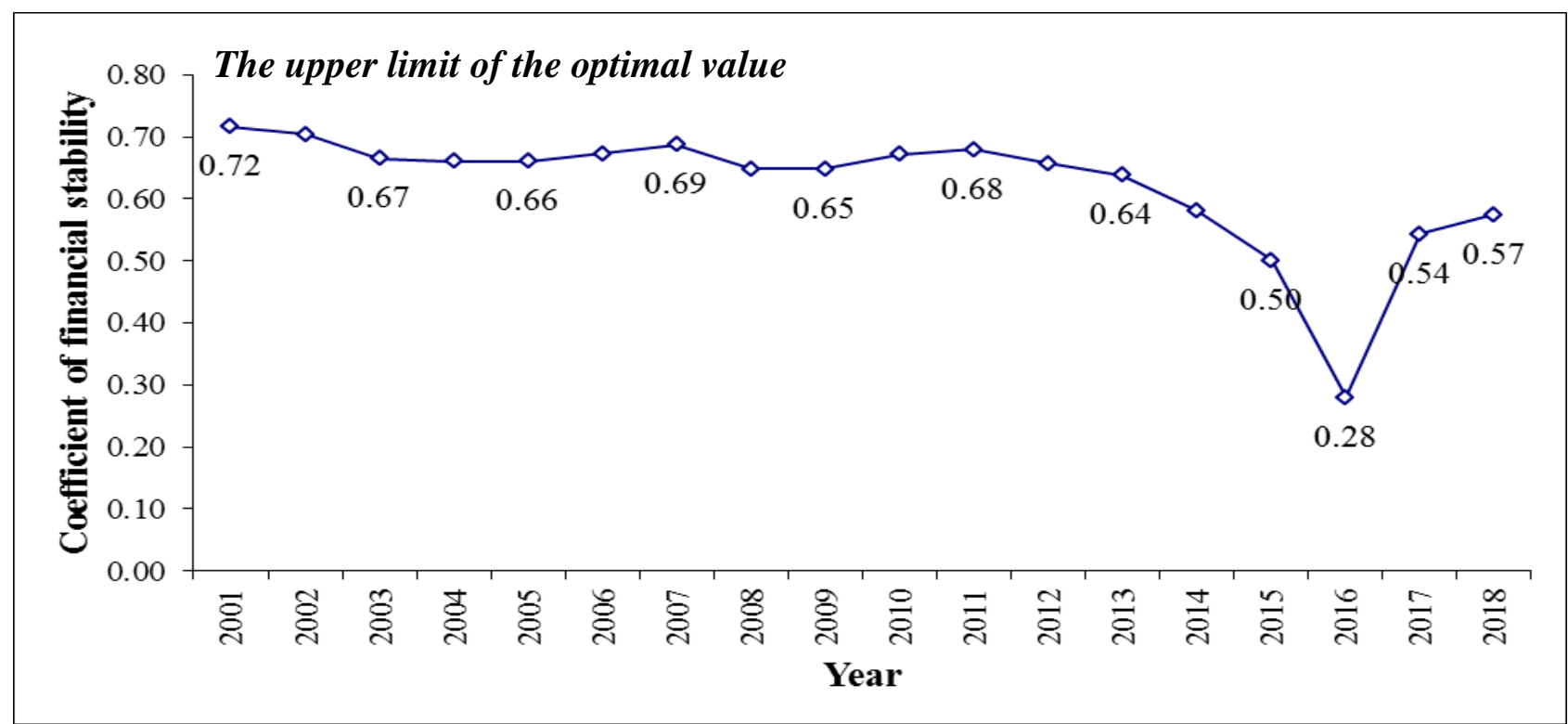

Fig. 6. Coefficient of financial stability of business entities in agriculture, forestry and fisheries of Ukraine

Source: calculated and built by the author based on data [17].

An indicator of financial stability, which indicates how the financial potential of the entity will change when the valuation of long-term liabilities changes, is the coefficient of financial independence of capitalized sources (Table 2).

The dynamics of increase of this indicator for the studied period is positive. The accumulation of capital encourages an increase in financial resources, and, consequently, the reproduction of capital on an expanded basis. However, it is necessary to carefully analyze the capital structure, because a significant increase in the share of debt instruments in financing economic activities, increasing the share of debt capital in the structure of total capital narrows the reproduction process and negatively affects financial stability. Based on the fact that the reproduction process is long-term, in this dimension, capitalized sources play a significant role. Economicand-mathematical modeling has an important place in determining the evaluation 
indicators of endogenous impact on the effectiveness of capital for effective management decisions regarding the agricultural sector of the economy and the formation of long-term forecasting $[8 ; 38 ; 39]$.

Table 2

Coefficient of financial independence of capitalized sources of economic entities in agriculture, forestry and fisheries of Ukraine

\begin{tabular}{|c|c|c|c|c|c|c|c|c|}
\hline \multirow{2}{*}{ Indicators } & \multicolumn{7}{|c|}{ At the end of the year } & \multirow{2}{*}{$\begin{array}{c}2018 / \\
2001,+,-\end{array}$} \\
\hline & 2001 & 2008 & 2014 & 2015 & 2016 & 2017 & 2018 & \\
\hline $\begin{array}{l}\text { Equity (Eq.), billion } \\
\text { UAH }\end{array}$ & 41.51 & 62.85 & 163.93 & 275.30 & 369.37 & 436.34 & 482.98 & 394.83 \\
\hline $\begin{array}{l}\text { Long-term liabilities } \\
\text { (LTL), billion UAH }\end{array}$ & 3.76 & 23.42 & 62.97 & 68.13 & 61.89 & 59.08 & 82.25 & 78.49 \\
\hline $\begin{array}{l}\text { Capitalized sources } \\
\text { (CS=Eq.+LTL), billion } \\
\text { UAH }\end{array}$ & 45.27 & 86.27 & 226.9 & 343.43 & 431.26 & 495.42 & 565.23 & 519.96 \\
\hline \multicolumn{9}{|c|}{ Coefficient of financial independence of capitalized sources = Eq.: CS } \\
\hline & 0.92 & 0.73 & 0.72 & 0.80 & 0.86 & 0.88 & 0.85 & -0.07 \\
\hline
\end{tabular}

Source: built by the author based on data [17].

The revealed research tendencies of change of cost and structural characteristics of capital in the agrarian sector of the economy of Ukraine and their correlation to the main economic indicators of the macro level give grounds to assert that there is a manifestation of financial instability in the agrarian sector of the economy. The «hypothesis of financial instability», as well as the definition of «financial fragility» was formulated by Hyman Philip Minsky [40]. Given that the agricultural sector of Ukraine with its basic component, agriculture, is a system-forming one in the national economy and forms the basis for preserving the sovereignty of the state (food, and within certain limits, economic, environmental and energy security), we assume that further accumulation of negative trends cost and structural characteristics of capital in the agricultural sector of Ukraine may be the basis for the acquisition of a state of financial fragility in the economic system as a whole.

Conclusions. The study on financial diagnostics of capital reproduction in the agricultural sector of Ukraine allowed to draw the following conclusions and suggestions: firstly - during the study period (2001-2018) the level of real capitalization in the agricultural sector of Ukraine was decreased significantly, therefore, the mechanism of financial policy reproduction of capital should be aimed at increasing internal sources of capital formation and optimizing the structure of total capital; secondly, usage of additional capital as a source of coverage of balance losses (provided that all other sources are used) to ensure a stable increase in capital in the process of economic and financial activities of economic entities; in this regard, it is necessary to take into account the corporate law of the EU Directives, which harmonize certain capital formation rules, namely, in accordance with the «fixed capital system» (enshrined in the Second EU Directive) we consider it expedient to make changes to the regulatory legal documents of Ukraine regarding the guaranteed real contribution of the authorized capital at the level of the value of 
the company's net assets and to consider such a level as the minimum allowable. The implementation of these proposals will have a positive impact on ensuring a sustainable expanded reproduction of capital in the agricultural sector of Ukraine's economy. The prospect of further research is the development and justification of effective financial and economic solutions in the field of capital reproduction management in the agricultural sector of the economy, taking into account a number of intersectoral links in the process of value movement at different stages of the capital reproduction cycle in relation to the stages of production, distribution, exchange and consumption of material goods.

\section{References}

1. Sabluk, P. T., Luzan, Yu. Ya. (2019), Agrarian policy and factors for its implementation. Economika APK, vol. 10, pp. 6-17. https://doi.org/10.32317/22211055.201910006.

2. Haiets, V. M. (2000), Nestabilnist ta ekonomichne zrostannia [Instability and economic growth], Institute of economics and forecasting of the National Academy of Sciences of Ukraine, Kyiv, Ukraine.

3. Danylenko, A. I., Zymovets, V. V. and Sheludko, N. M. (2015), Decapitalization of Ukraine's financial sector: causes and consequences. Economics and forecasting, vol. 4, pp. 7-28. https://doi.org/10.15407/eip2015.04.007.

4. Turylo, A. A. (2013), Theoretical and methodological principles of determining the nature and evaluation of capitalization of the enterprise. Teoretychni i praktychni aspekty ekonomiky ta intelektual'noii vlasnosti, vol. 2, no. 1, pp. 159162.

5. Balitska, V. V. (2007), Kapital pidpryiemstv Ukrainy: tendentsii, priorytety [Capital of enterprises of Ukraine: trends, priorities], Institute of economics and forecasting of the National Academy of Sciences of Ukraine, Kyiv, Ukraine.

6. Davydenko, N. and Lemishko, O. (2019), Pro-European orientation of Ukraine adaptation of the agricultural policy of Ukraine to the conditions and requirements of the European Union. Proceedings of the 2019 international conference «Economic science for rural development» no. 52. Jelgava, LLU ESAF, 9-10 May 2019, Latvia. https://doi.org/10.22616/ESRD.2019.127.

7. Kostyrko, L. A., Kostyrko, R. O., Madiyarova, E. S. and Sereda, O. O. (2018), Comprehensive analysis of investment attractiveness of enterprises in the context of financial support for enterprise development. Financial and credit activities: problems of theory and practice, vol. 2, no. 25, pp. 198-207. https://doi.org/10.18371/fcaptp.v2i25.136555.

8. Sholoiko, A. (2017), Financing losses from natural and man-made disasters by use of crowdfunding. Investment management and financial innovations, vol. 14, is. 2, pp. 218-225. https://doi.org/10.21511/imfi.14(2-1).2017.07.

9. Kasych, A. and Vochozka, M. (2017), Theoretical and methodical foundations of sustainable management in modern companies. Marketing and management of innovations, no. 2, 298-305. https://doi.org/10.21272/mmi.2017.2-28. 
10. Oliynyk-Dunn, O., Adamenko, V and Zufan, P. (2017), Comparative analysis of debt financing models in Czech and Ukrainian agricultural enterprises. Acta universitatis agriculturae et silviculturae mendelianae brunensis, vol. 65, is. 5, pp. 1729-1739. https://doi.org/10.11118/actaun201765051729.

11. Soliwoda, M. and Pawlowska-Tyszko, J. (2014), Agricultural taxation in Poland vs. solutions in selected EU countries. Economic science for rural development, no. 33, pp. 99-107.

12. Kuzmenko, S., Perederiy, N. and Labenko, O. (2016), Market trends of oilseeds production in Ukraine. International Scientific Days 2016. The agri-food value chain: challenges for natural resources management and society. Slovak University of Agriculture in Nitra, Nitra, Slovak. https://doi.org/10.15414/isd2016.s1.04.

13. Kvasha, S., Davydenko, N., Ivanko, A. and Titenko, Z. (2019), Modeling the partial equilibrium in the milk and dairy market in Ukraine. Journal of environmental science and management, vol. 5, spec. is., pp. 78-86. https://doi.org/10.22034/GJESM.2019.05.SI.09.

14. Novak, I., Verniuk, N. and Novak, Yu. (2016), Structuring of sources of attracting capital to agricultural production as a prerequisite for the formation of an effective investment mechanism in the agricultural sector. Economic Annals-XXI, vol. 159, is. 5-6, pp. 29-33. https://doi.org/10.21003/ea.V159-06.

15. Levchenko, N. V. and Ohlikh, V. V. (2012), Estimation methods for investment attractiveness of agrarian business in Ukrainian regions in the context of strategic planning. Actual problems of economics, vol. 8, pp. 285-293.

16. Zadorozhnyi, Z.-M. and Yasyshena, V. (2019), Intangible assets as an accounting and management object. Marketing and management of innovations, vol. 1, pp. 132-142. http://doi.org/10.21272/mmi.2019.1-10.

17. State Statistics Service of Ukraine (2019), Statystychnyi shchorichnyk Ukrainy za 2018 rik [Statistical Yearbook of Ukraine for 2018], State Statistics Service of Ukraine, Kyiv, Ukraine.

18. Balytska, V. (2011), Resource provision of the national economy: declared goals and the real situation. Actual problems of economics, vol. 12, pp. 73-84.

19. Tereshchenko, G. M. (2015), Decapitalization of non-bank financial institutions: factors and consequences. Economics and forecasting, vol. 3, pp. 42-57.

20. Zhdanova, L. L. (2014), Reproduktsiia i nahromadzhennia kapitalu: teoriia, metodolohia, ekonomichna polityka [Reproduction and accumulation of capital: theory, methodology, economic policy], Astroprynt, Odesa, Ukraine.

21. Lunkina, I. T. (2013), Sustainable economic development of Ukraine, its nature and meaning. Ukrainian Black Sea region agrarian science, vol. 2(72), pp. 35-41.

22. Nikonova, Ya. I. (2010), Innovatsionnaya politika $v$ sisteme gosudarstvennogo regulirovaniya ustoychivogo razvitiya natsional'noy ekonomiki [Innovation policy in the system of state regulation of sustainable development of the national economy], NGTU, Novosibirsk, Russia. 
23. Havrylenko, T. V. (2016), Financial support of the enterprises in modern conditions. Internauka, vol. 12(2), pp. 47-48.

24. The Verkhovna Rada of Ukraine (2003), The Law of Ukraine «On farming», available at: http://zakon2.rada.gov.ua/laws/show/973-15.

25. Chernodubova, E. V. and Temnikova, N. V. (2009), Financial system of Ukraine: problems and prospects of development. Efektyvnist' upravlinnia operatyvnoiiu diial'nistiu iak skladova zabezpechennia finansovoii stabil'nosti pidpryiemstva [Management efficiency of operational activity as a component of ensuring the financial stability of the enterprise]. III Mizhnarodna naukovopraktychna konferentsia [III International scientific-practical conf.], Ekomen, Kyiv, November 16, pp. 181-184.

26. The Verkhovna Rada of Ukraine (2011), The Law of Ukraine «On Amendments to Certain Legislative Acts of Ukraine Concerning the Simplification of the Procedure for Starting a Business», available at: https://zakon.rada.gov.ua/laws/show/3263-17\#Text.

27. State Committee for Entrepreneurs of Ukraine (2004), Letter «On the formation of an authorized capital by a private enterprise», available at: https://zakon.rada.gov.ua/rada/show/v1858563-04/sp:java-:max25.

28. The Verkhovna Rada of Ukraine (1991), The Law of Ukraine «On business associations», available at: http://zakon2.rada.gov.ua/laws/show/1576-12.

29. The Verkhovna Rada of Ukraine (2008), The Law of Ukraine «On jointstock companies», available at: http://zakon2.rada.gov.ua/laws/show/51417/ed20111218.

30. The Verkhovana Rada of Ukraine (2018), The Law of Ukraine «About limited and additional liability companies», available at: http://zakon2.rada.gov.ua/laws/show/2275-19.

31. Korotash, Ya. O. (2014), Determination of the minimum size of the authorized capital of limited liability companies. Administrative law and process, vol. 3 (9), pp. 216-222.

32. Directive 2012/30/EU of the European Parliament and of the Council (2012), On coordination of safeguards which, for the protection of the interests of members and others, are required by Member States of companies within the meaning of the second paragraph of Article 54 of the Treaty on the Functioning of the European Union, in respect of the formation of public limited liability companies and the maintenance and alteration of their capital, with a view to making such safeguards equivalent, OJ L 315, October 25, pp. 74-97.

33. Glinkowska, B. and Chebotarov, V. (2018), A comparative cross-cultural analysis of the profile of a modern Ukrainian manager: the imperatives of the future in the context of internationalization. Comparative Economic Research, vol.21, no. 3, pp. 63-74. https://doi.org/10.2478/cer-2018-0019.

34. Glinkowska, B., Chebotarov, Ie. and Chebotarov, V. (2020), Comparative studies of national business cultures in the countries of Central and Eastern Europe: the basics for improving international entrepreneurship in Poland and Ukraine. 
Agricultural and Resource Economics: International Scientific E-Journal http://are-journal.com

Comparative Economic Research, vol. 23,
https://doi.org/10.18778/1508-2008.23.01.

35. Lyuta, O. V., Boyarko, I. M. and Pigul, N. G. (2012), Improving methods for assessing the financial stability of the local budget. Current economic problems, no. 9. pp. 194-201.

36. Hravel, E. Yu. (2007), Methodical approaches to assessing the financial stability of enterprises. State and regions, no. 1, pp. 91-93.

37. Sarapina, O. A. (2013), System analysis of the financial condition of the enterprise: methods and areas for improvement. Scientific bulletin of Kherson State University. Series «Economic sciences», no. 1, pp. 96-99.

38. Haldane, A. (2004), Financial stability and macroeconomic models. Financial stability review, no. 16, pp. 80.

39. Lemishko, O. (2018), Modeling of endogenous factors impacting the efficiency of aggregate capital in Ukraine's agriculture. Economic Annals-XXI, vol. 170, is. 3-4, pp. 10-14. https://doi.org/10.21003/ea.V170-02.

40. Minsky, H. (1977), The financial instability hypothesis: an interpretation of keynes and an alternative to «standard» theory. Nebraska journal of economics and business, vol. 16, no. 1, pp. 5-16.

How to cite this article? Як цитувати цю статтю?

Стиль-ДСТУ:

Lemishko O. Formation of analytical tools of capital reproduction in the agricultural sector of Ukraine. Agricultural and Resource Economics. 2020. Vol. 6. No. 3. Pp. 64-79. URL: http://are-journal.com.

Style-Harvard:

Lemishko, O. (2020), Formation of analytical tools of capital reproduction in the agricultural sector of Ukraine. Agricultural and Resource Economics, vol. 6, no. 3, pp. 64-79, available at: http://are-journal.com. 